УАK 339.9

M. B. Фeдuк,

к.е.н., асистент кафедри аналітичної економії та міжнародної економіки, Аьвівський начіональний університет імені Івана Франка

ORCID ID: 0000-0002-1067-6843

DOI: $10.32702 / 2306-6806.2021 .7 .40$

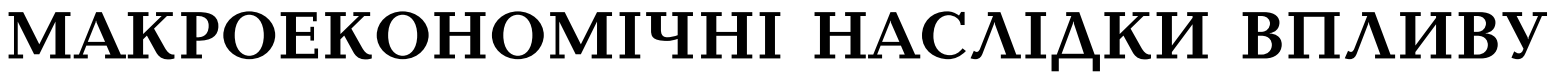 ПАНАЕМIÏ COVID-19 HA CВITOBУ EKOHOMIKУ
}

\author{
M. Fedyk, \\ PhD in Economics, Assistant of the Department of Analytical Economy
}

and International Economics at Ivan Franko National University of Lviv

\section{MACROECONOMIC CONSEQUENCES OF THE IMPACT OF THE COVID-19 PANDEMIC ON THE GLOBAL ECONOMY}

Поширення коронавірусної хвороби COVID-19 у Світовомумасштабі зумовило скорочення торгівельних операцій між країнами, зайнятості, падіння обсягів виробництва в окремих секторах економіки (туризм, продовольча сфера, ресторанний бізнес, торгівля). Мета статті полягала у виявленні впливу наслідків пандемії COVID-19 на світову економіку. У, ослідженні ідентифіковано превалювання негативних наслідків впливу на економіку країн світу у зв'язку 3 поширенням пандемії у таких секторах економіки: туризм, цивільна авіація, промислове виробництво (карантинні обмеження призвели до повної зуПинки деяких виробництв), сфера роздрібної торгівлі, індустрія розваг та Спорту тощо. Падіння виробництва у вказаних секторах призвело до скорочення обсягів доходів, торгівельних операцій та обсягів наданих послуг. Країни, в яких частка цих секторів у ВВП була найбільшою, більшою мірою постраждаАи від Поширення Пандемії. У Статті виявлено, що зміна поведінки споживачів У зв'язку з карантинними обмеженнями визначила обсяги виробництва товарів та послуг у різних секторах економіки: транспортному, туристичному, ресторанному, промисловому та продовольчому. Попри негативні наслідки через зміну соціальних шаблонів поведінки індивідуумів, пандемію можна розГдядати як "чорний лебідь", який очистив економіку ві, неплатоспроможних ПідПриємСтв, які завдяки низьким відсотковим Ставкам кредитували вАаснУ Аіяльність. Позитивними наслідками вПливу на економічну Систему через поширення Пандемії можна вважати розвиток новітніх секторів економіки: нових сервісів, зокрема сервісів доставки, побудованих на цифрових бізнес-моделях та додатках. Виявлено, що початкові оцінки впливу пандемії на економіку значно переоцінені, адже фактичні, дані 2020 року свідчать про скорочення обсягів виробництва в певних країнах та незначне падіння ВВП в інших через різну структуру економіки та поведінку економічних агентів.

The spread of the coronavirus disease COVID-19 on a global scale has led to a decrease in trade between countries, employment, a drop in production in certain sectors of the economy (tourism, food, restaurant business, trade). The purpose of the academic paper was to identify the impact of the COVID-19 pandemic on the global economy. The research has identified the prevalence of negative consequences of the impact on the world countries' economies in connection with the spread of the pandemic in such sectors of the economy as follows: tourism, civil aviation, industrial production (quarantine restrictions have led to the complete cessation of some industries), retail, entertainment and sports, etc. The decline in production in the sectors outlined has led to a reduction in revenues, trade and services provided. Countries, in which the share of these sectors in GDP was the largest, were most affected by the spread of the pandemic. The academic paper has revealed that the change in consumer behavior due to quarantine restrictions has determined the volume of production of goods and services in various sectors of the economy, namely: transport, tourism, restaurants, industry and food. Despite the negative consequences due to changing social patterns of individuals' behavior, the pandemic can be considered as a "black swan" forasmuch as it has cleared the economy of insolvent enterprises that have lent their own activities due to low interest rates. The development of the newest sectors of the economy, namely: new services, in particular delivery services, built on digital business models and applications, can be considered as the positive 
consequences of the impact on the economic system due to the spread of the pandemic. It has been revealed that the initial estimates of the impact of the pandemic on the economy are significantly overestimated, forasmuch as the actual data for 2020 indicate a decrease in production in certain countries and a slight drop in GDP in other countries through a different structure of the economy and the behavior of economic agents.

Ключові слова: пандемія COVID-19, економічна речесія, світова економіка, міжнародна торгівля, макроекономічні наслідки, мікроекономічні наслідки.

Key words: COVID-19 pandemic, economic recession, global economy, international trade, macroeconomic consequences, microeconomic consequences.

\section{ПОСТАНОВКА ПРОБЛЕМИ}

Вперше захворювання на COVID-19 було виявлено у китайському місті Ухань, провінція Хубей. Ще тоді людство не передбачало катастрофічного масштабу цієї загрози як для життя людей, так і для світової економіки загалом. Проте за останніми даними Всесвітньої організації охорони здоров'я (ВОО3) за період 20 січня 2020 року - 5 липня 2021 року зареєстровано $183,368,584$ млн випадків захворювання та 3975503 смертей у всьому світі [23]. Число смертельних випадків $€$ вражаючим, з огляду на коефіцієнт летальності від $2 \%$ до $3,4 \%$, в той час рівень смертності від грипу становить $1 \%$. Отже, розуміємо, що людські втрати є найбільшим чинником спаду світової економіки. Попри досить оперативне реагування міжнародної спільноти щодо створення вакцини та початку вакцинації найбільш вразливих до вірусу соціальних груп населення, зараз неможливо точно спрогнозувати кількість людських жертв та економічних втрат, яких зазнають країни внаслідок пандемії. Однак важливо виявити теперішні наслідки впливу пандемії на світову економіку та здійснити аналіз заходів, котрі запроваджують уряди країн для боротьби з економічною рецесією. Це дасть можливість спрогнозувати розвиток економічної ситуації в короткостроковій перспективі.

\section{АНАЛІЗ ОСТАННІХ ДОСЛІДЖЕНЬ ТА ПУБЛІКАЦІЙ}

Аослідженню наслідків впливу пандемії на світову економіку присвячено роботи Аолбнєва А.В. [4], Грицюк Н.О., Сак Т.В. [2], Гурріа К. [3], Якимишин I. [8], Гололобова О., Чмельова О.[1], Радченко М.О., Рудь В.О. [5], Терещук С.В., Назаров М.I. [7]. Науковцями систематизовано такі основні наслідки: падіння індексів бірж; швидке та масштабне зниження попиту та цін на нафту та уповільнення розвитку ринку металів; сповільнення темпів споживчого попиту, як наслідок скорочення виробництва, зокрема обсягів промисловості; суттєве зниження доходів авіакомпаній та морського транспорту, торгово-розважальних центрів, туристичної індустрії; зростання заміщення товарів; зменшення доходів населення та зміни поведінки споживачів; зростання прибутків фармацевтичної промисловості та світової індустрії ігрових, освітніх та інших онлайн-додатків; зростання попиту інвесторів на менш ризикові активи. Загалом криза через поширення пандемії призвела до структурних зрушень в економіці та на світових товарних ринках. У певних секторах економіки почали розвиватися та зростати нові сегменти, для прикладу, зростає ринок доставки товарів та послуг.

\section{META CTATTI}

Метою статті є виявлення та класифікація макроекономічних наслідків впливу пандемії на світову економіку.

\section{ВИКЛАД ОСНОВНОГО МАТЕРІАЛУ ДОСЛІДЖЕННЯ}

Американський трейдер, письменник Нассім Ніколас Талеб у книзі "Антикрихкість. Про неймовірне в реальному житті" [6], яка вийшла у 2007 році, вперше ввів поняття "чорний лебідь", що означає подію, яка має значні наслідки, котрі неможливо передбачити, проте постфактум вони радикально змінюють нашу реальність, в результаті цього у людей виникає ілюзія закономірності таких явищ. 3 початком пандемії COVID-19 у Китаї, а потім у США та Европі дуже багато аналітиків та експертів почали стверджувати, що це власне і $€$ той "чорний лебідь", котрий раптово з'являється та змінює хід світової історії. Проте, з нашої точки зору, вірус з'явився не настільки непередбачено як це про це стверджують засоби масової інформації. У 2016-2017 році дуже багато науковців заявляли про високу ймовірність виникнення небезпечних вірусів. Зокрема, було опубліковано багато наукових статей на цю тематику. У 2015 році під час виступу на щорічній міжнародній конференції TED (майданчику, де обговорюються "ідеї, котрі гідні розповсюдження") Білл Гейтс, аналізуючи ситуацію з вірусом Еболою, закликав людство "витрачати величезні кошти не на ядерні ракети, а на боротьбу з особливо небезпечними вірусами" [18]. Такі застереження не привернули достатньої уваги світових лідерів, які, з огляду на існуючі біологічні загрози, могли б розробляти та впроваджувати необхідні превентивні захоАи.

Отже, проблема виникнення небезпечних для людства вірусів не набула пріоритетного значення та була проігнорована з боку впливових світових еліт та урядів країн, тому блискавичне розповсюдження вірусу з китайської провінції Хубей на решту частини світу, призвело до того, що 11 березня 2020 року ВООЗ оголосила про початок пандемії COVID-19. Аля стримування стрімкого розповсюдження інфекції та захисту життя й здоров' я своїх громадян, більшість країн змушені були запровадити жорсткі карантинні обмеження у першій половині 2020 року, що в свою чергу призвело до різкого скорочення економічної діяльності у глобальному масштабі.

Проте маємо зауважити, що основна проблема полягає не лише у значних економічних втратах, котрих зазнала світова економіка, а в тому, що пандемія спричинила спад темпів економічного розвитку, оскільки відбулось накладання економічного спаду, спровокованого пандемією коронавірусу, на фазу рецесії світової економіки, яка прогнозувалась на період 2019-2020 рр. Як відомо, економічні кризи не є несподіванкою, а виникають через певні проміжки часу, котрі економісти називають економічними циклами. Остання світова фінансово-економічна криза (також відома як Велика Рецесія) розпочалась падінням ринкової економіки у 


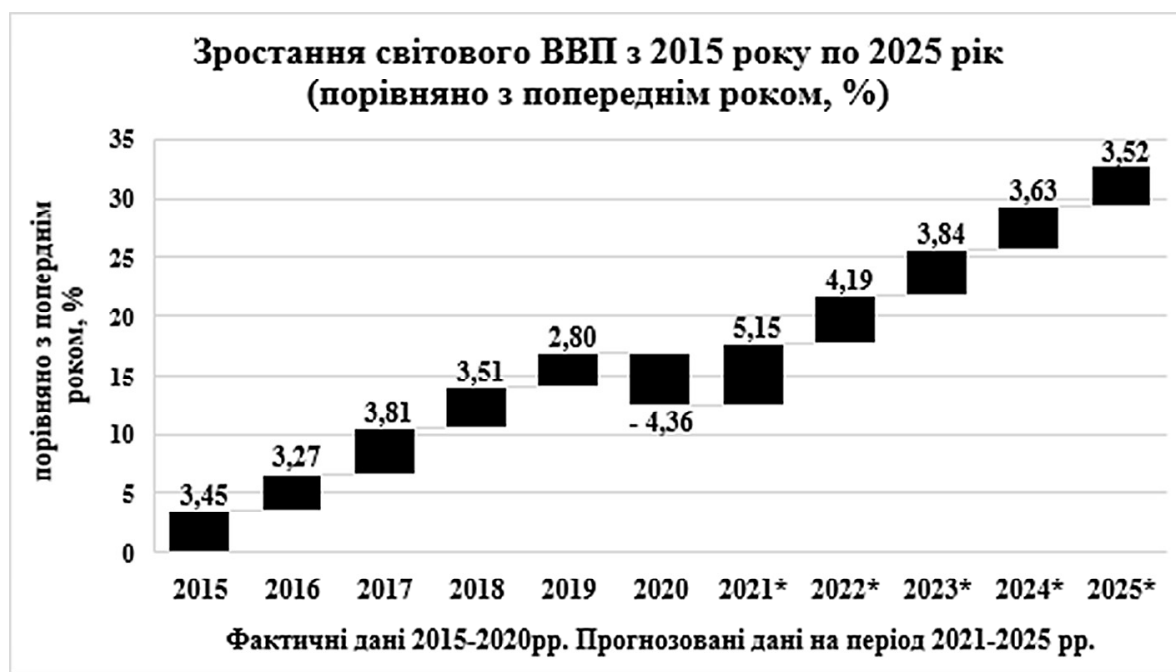

Рис. 1. Світовий ВВП за період 2015-2020 рр., $2021-2025$ рр. (прогноз) які від них постраждали, темп економічного зростання сповільнювався до 2,4\% у порівнянні 3 іншими країнами [11]. Водночас після припинення епідемій економічне зростання країн прискорювалось.

Пандемія COVID-19 триває півтора року, за цей час вона суттєво вплинула на розвиток світової економіки, оскільки не оминула жодну 3 країн. Загалом статистика показує, що у 2020 році світовий ВВП зменшився приблизно на $4,36 \%$ порівняно 3 попереднім роком. Зокрема, ВВП ЕС у 2020 році скоротився на 7,4 \%. Найбільше постраждали економіки таких країн як Іспанія та Великобританія, де ВВП зменшився на $12,4 \%$ та $10,3 \%$ відповідно, при цьому ВВП Аитви скоротився лише на $2,2 \%$, тому ця країна зазнала найменшої шкоди [13]. Проте за прогнозами МВФ, у 2021 році очікується по- грудні 2007 року і досягла найбільшого піку у вересні 2008 року. Отже, від часу останньої фінансово-економічної кризи пройшло 12 років.

У 2020 році пандемія зупинила відновлення світової економіки після попередньої кризи - Великої рецесії 2007-2009 року. Невтішні прогнози та невизначеність, пов'язана з початком пандемії на початку 2020 року, призвели до розбіжностей між двома найбільшими виробниками нафти, Росією та Саудівською Аравією. Попит на нафту різко знизився після введення жорстких карантинних обмежень на подорожі у березні 2020 року. Таким чином, основним каталізатором економічної кризи 2020 року стало падіння цін на нафту на світовому ринку. Зокрема, за період 6-9 березня 2020 року ціна на нафту на світових ринках опустилася на $34,65 \%$, а це найнижчий результат з 1991 року [10]. Як наслідок, у I кварталі 2020 року фондові біржі у цілому світі втратили в основному понад 20\% своєї вартості, зафіксувавши найнижчі результати в порівнянні з світовою фінансовою кризою 2007-2009 рр. Отож, в середині 2020 року розпочалась нова глобальна економічна криза, спровокована пандемією COVID-19.

Здійснюючи аналіз попередніх епідемій, а саме: грипу H1N1 (2009-2010рр.) чи вірусу Еболи (2014-2016 pp.), можемо відзначити, що пандемія коронавірусу становить більш широкомасштабну загрозу для світової економіки. Оскільки під час попередніх епідемій в країнах, жвавлення світової економіки та зростання світового ВВП на $5,15 \%$. Аналізуючи прогноз світового ВВП впродовж періоду 2021-2025 рр., можемо передбачити, що у найближчі роки виробництво стане ще швидшим та більш глобальнішим, що сприятиме зростанню світової економіки.

Загалом карантинні обмеження торкнулися близько половини усього населення світу і негативно впливають на національні економіки різних країн. Аналізуючи стан семи найбільших економік світу, маємо констатувати той факт, що найбільш негативного впливу через пандемію COVID-19 зазнала саме Великобританія. Станом на третій квартал 2020 року темпи зростання ВВП Великобританії становили -9,6\% порівняно з попереднім роком. Крім того, ВВП Індії скоротився на 7,5\%. Аише Китай зазнав позитивних темпів зростання ВВП у $4,9 \%$ за той самий період. Впродовж першої половини 2020 року Китай також продемонстрував позитивні темпи зростання довіри до бізнесу $(+1,6 \%)$. Таким чином, попри світову економічну кризу, спричинену пандемією, передбачається, що до 2030 року Китай затьмарить США і матиме найбільший у світі ВВП - 31,7 трлн дол. За прогнозами МВФ, США матимуть другий за величиною ВВП - 22,9 трлн дол. Зазначимо, що у 2019 році ВВП Китаю становив близько 14,73 трлн дол., а вже у 2020 році ВВП Китаю досяг близько 15,67 трлн дол. У 2020 році США має найбільший ВВП у світі $-20,5$ трлн дол.,

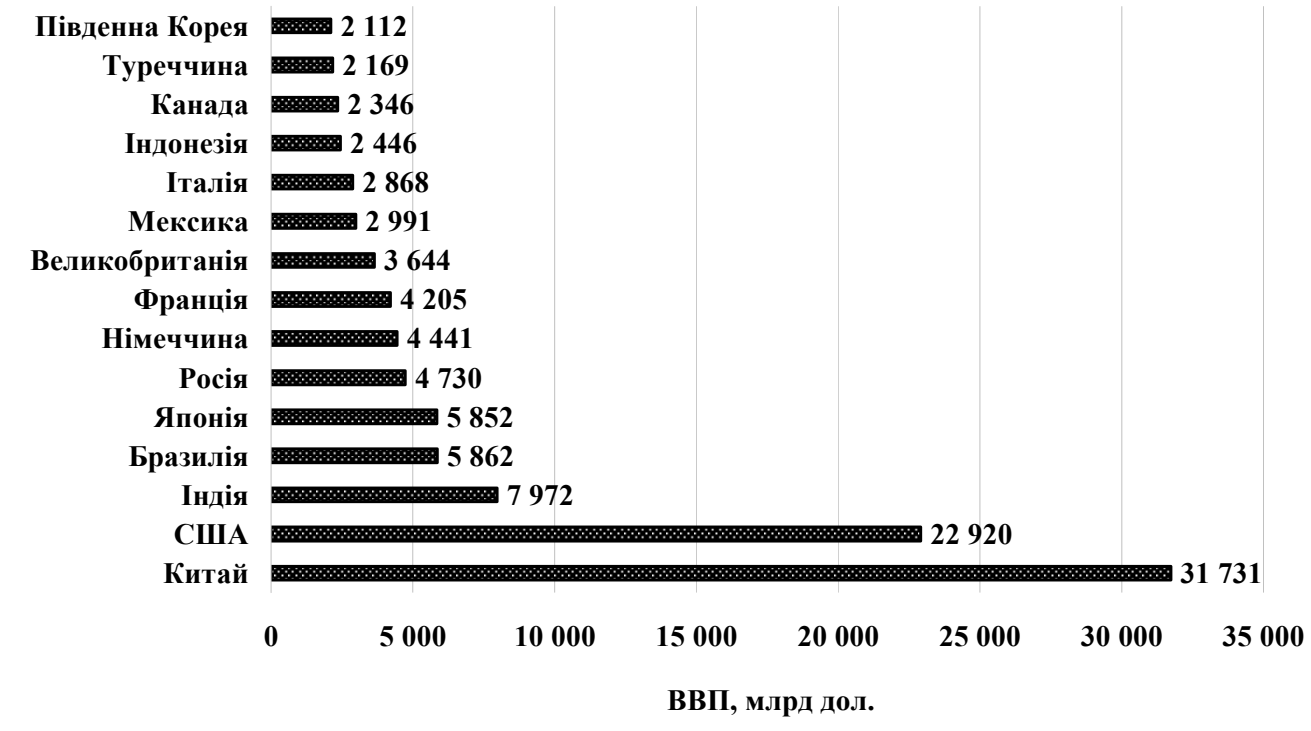




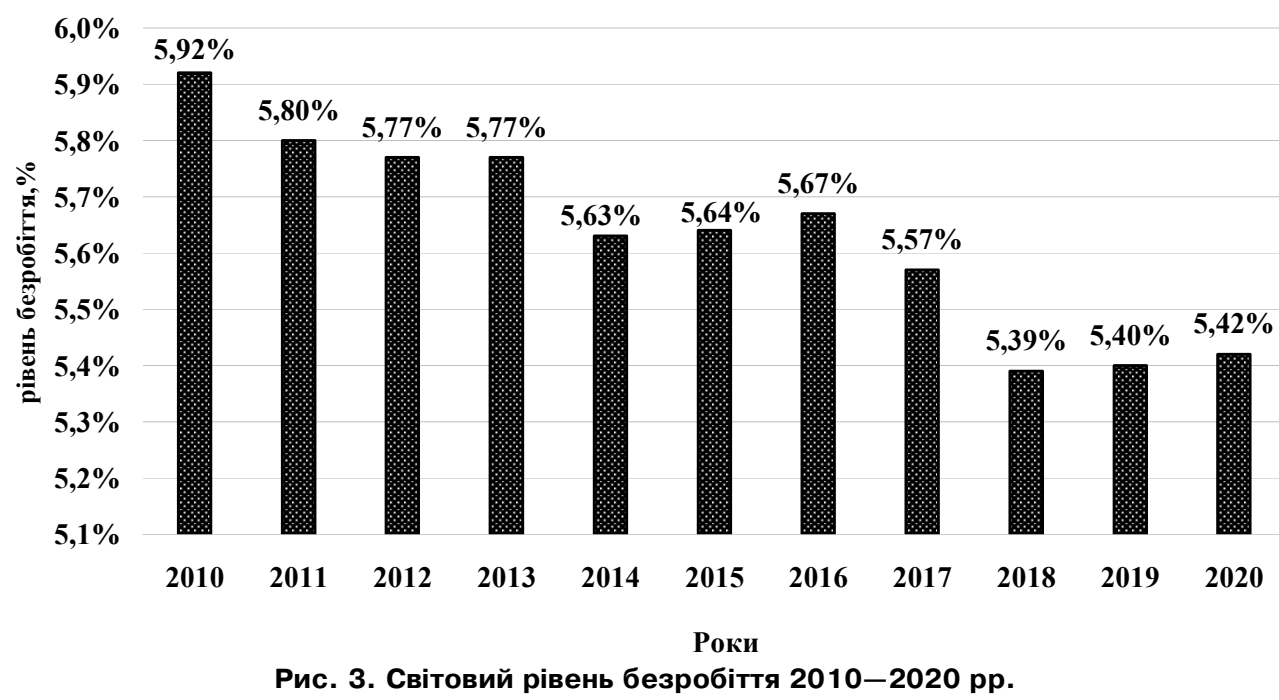

Ажерело: [22].

ВВП Китаю є другим за величиною і становить 13,4 трлн дол.

За останні чотири роки ріст міжнародної торгівлі досяг найнижчого рівня у другому кварталі 2020 р. зі скороченням на $13 \%$ порівняно $з$ попереднім кварталом 2019 року. Маємо зазначити, що скорочення міжнародної торгівлі, передусім пов'язане з порушенням функціонування світової транспортної системи. Адже доставка вантажів у портах забезпечує понад 80 \% світової торгівлі товарами та становить приблизно $70 \%$ від його вартості, оскільки цей сектор економіки зв'язує між собою ланцюги постачання та ринки у всьому світі. Тому глобальні виклики, пов'язані з обмеженнями через пандемію, спричинили серйозне порушення усієї світової транспортної системи. Карантинні заходи та обмеження, котрі запровадили уряди країн, спричинили перебої у роботі міжнародних ланцюгів постачання, що призвело до негативних соціальних та економічних наслідків у відповідних країнах. Ао прикладу, морський транспорт стикнувся 3 такими проблемами: 1) проблеми 3 часом виконання доставки; 2) порожні плавання; 3) закриття портів; 4) дефіцит робочої сили та внутрішнього транспорту; 5) обмеження ємності вантажів. Проте основним викликом для морського транспорту під час карантинних обмежень у 2020 році було забезпечення ефективних змін екіпажу.

Пандемія COVID-19 здійснила також негативний вплив на пряму іноземну інвестиційну діяльність у 2020 році. Перспективи залишаються жахливими, подальше погіршення прогнозується до початку 2022 року, адже теперішні виняткові обставини в результаті пандемії призвели до затримки реалізація поточних інвестиційних проєктів та відкладання впровадження нових проектів, а також до зниження іноземних інвестиційних доходів [19].

Однак найболючішою проблемою для усіх без винятку країн залишається зростання рівня безробіття населення. У першому кварталі 2020 року було втрачено близько 5,4\% робочого часу. За даними Міжнародної організації праці (МОП), кількість відпрацьованих годин в Америці у аругому кварталі 2020 року становила $12 \%$, у Європі, Азії та Африці11,8\%. Подібним чином МОП передбачає подальші втрати робочого часу у другому півріччі цього року. Це передусім залежатиме від перебігу COVID-19 в осінній та зимовий період. Очікується також збільшення кількості людей, які живуть в умовах крайньої бідності, на $0,8-$ $1,5 \%$. Це на 50-70 мільйонів більше, ніж прогнозувалося до епідемії [7].

Міжнародна організація праці (МОП) зазначає, що працюючі жкінки є особливо вразливими під час кризи, оскільки підааються більшому ризику втратити роботу. Оцінки МОП також свідчать про те, що найбільше страждають працівники країн, що розвиваються, особливо ті, хто працює у неформальній зайнятості. Зростання безробіття, скорочення робочого часу, тимчасові звільнення, знеохочення працівників та пошук роботи призвели до скорочення загального робочого часу, за оцінками МОП, на 14 \% у другому кварталі 2020 року порівняно з четвертим кварталом 2019 року. Це зниження загального робочого часу є еквівалентним 400 мільйонам штатних робочих місць [20].

Аналізуючи світовий рівень безробіття впродовж 2010-2020 pр., бачимо, що у 2020 році він зріс на $0,02 \%$ в порівнянні з попереднім роком та становить 5,42\%, Проте рівень безробіття по всьому світі у 2010 році був значно вищим - 5,92\%, тобто на $0,5 \%$ більше в порівнянні з 2020 роком.

Якщо досліджувати динаміку рівня безробіття окремих країн, то побачимо більш критичнішу ситуацію. Ао прикладу, рівень безробіття в США у 2019 році ста-

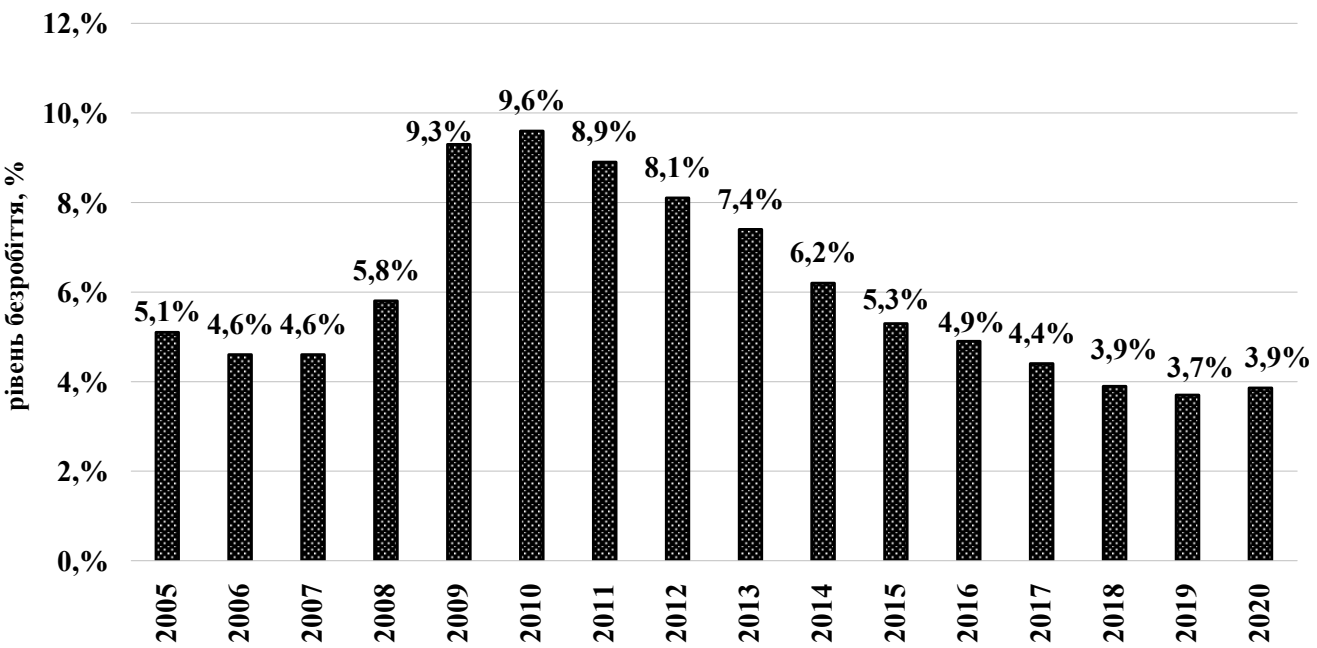

Ажерело: [17].

Рис. 4. Рівень безробіття в США впродовж 2005-2020 рр. 


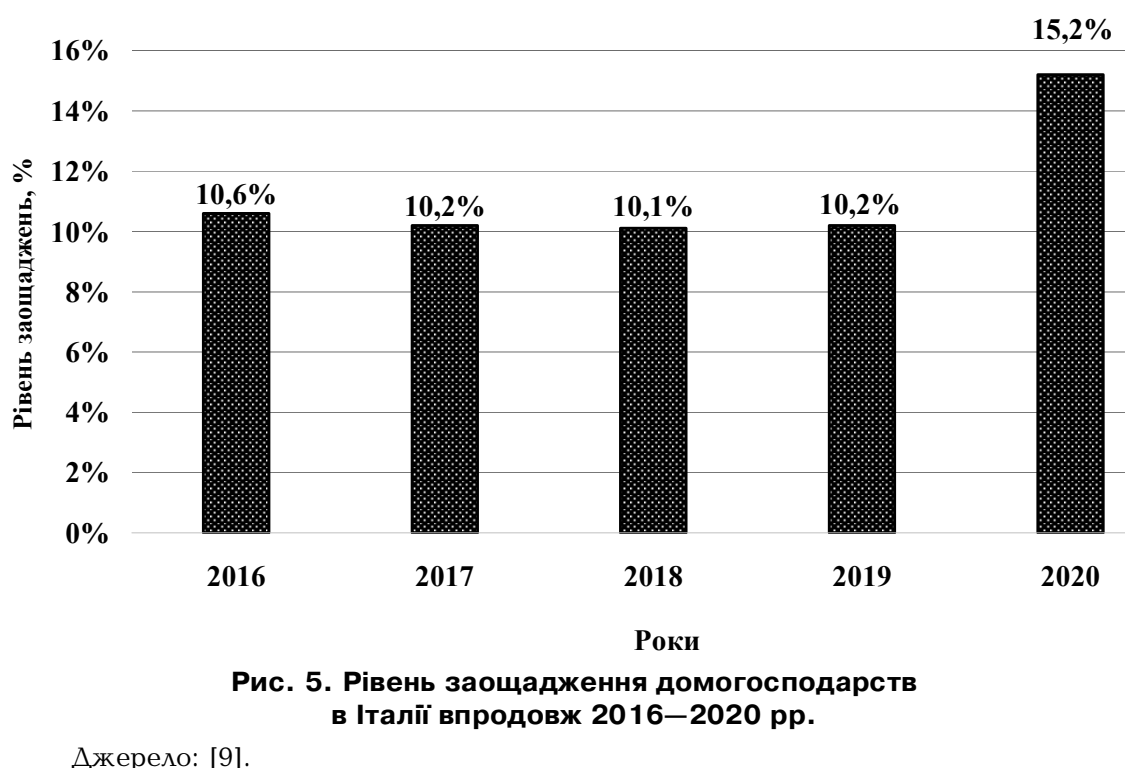

новив $3,7 \%$, а в 2020 році досяг $8,1 \%$, тобто зріс на $4,4 \%$. Хоча маємо зазначити, що США зазнали найвищого зростання рівня безробіття за останні 15 років після фінансової кризи 2007-2009 рр., котра призвела до його суттєвого зростання: 9,3\% у 2009 році та $9,6 \%$ у 2010 році, згодом впродовж 2010-2019 рр. спостерігалась рівномірна тенденція його зниження, проте пандемічний 2020 рік спровокував різке підвищення.

Пандемія спричинила невідповідність між споживацькими тенденціями та біофізичними потребами людей. Адже під час введення жорстких карантинних обмежень поведінка багатьох споживачі стала тривожною. Негативні очікування змусили споживачів панічно скуповувати велику кількість товарів першої необхідності (іжа, санітарно-гігієнічні товари).

Очевидно, що економічні втрати, спричинені пандемією COVID-19, значною мірою зумовлені падінням попиту. Оскільки запровадженні карантинні обмеження у багатьох країнах призвели до різкого падіння доходів домогосподарств, що, в свою чергу, зумовило суттєве зниження споживчого попиту на світовому ринку товарів та послуг, тобто це означає, що споживачі сьогодні не мають змоги купувати товари та послуги, доступні на світовому ринку.

Ао прикладу, впало споживання продуктів (окрім споживання товарів першої необхідності), причому найбільше постраждала сфера послуг, включаючи послуги у ресторанному бізнесі. Очевидно, що пандемія завдала неймовірних збитків світовій ресторанній галузі. Адже через заходи соціальної дистанції у громадських місцях споживачі їдять все менше і менше. За даними джерела, 10 березня 2021 року у річному обчисленні зменшення кількості ресторанів по всьому світу складає $48,5 \%$ [3].

Зокрема, введенні жорсткі обмеження на подорожування, призвела до того, шо велика кількість людей не змогла придбати квитки для відпочинку чи відрядження, внаслідок цього світова туристична сфера зазнала неймовірних збитків. Світовий ринок подорожей $\mathrm{i}$ туризму у 2020 році втратив 100 мільйонів робочих місць у всьому світі, особливої шкоди зазнав Азіатсько-Тихоокеанський регіон, оскільки він має найбільшу кількість робочих місць у сфері туризму. Загальний дохід Аля галузі подорожей та туризму зменшився приблизно на $42,1 \%$ порівняно з 2019 роком та становить у 2020 році - 396,37 млра дол. [20].

Ще одним негативним фактором впливу на туристичну сферу став шок або ж страх. Страх перед інфікуванням COVID-19 призвів до значної невизначеності та хаотичних дій людей не лише у туризмі, а й у багатьох інших сферах економіки. Адже шок впливає як на почення обсягів доходів туризму до 1,2 вьйона у 2020 році, світовий ВВП може скоротитися на $1,5 \%$ у 2020 році.

Окрім туристичної сфери, суттєвих збитків зазнала цивільна авіація, промислове виробництво (карантинні обмеження призвели до повної зупинки деяких виробництв), сфера роздрібної торгівлі, індустрія розваг та спорту тощо.

Схожа динаміка стосується й інших індустрій, наприклад, падіння попиту на нові машини чи нафту, оскільки щоденні поїздки на роботу, святкування або громадські заходи заборонені під час карантинних обмежень. Крім того, відсутність працівників на підприємствах порушила функціонування глобального ланцюжка створення вартості (global value chains, GVC), обмежуючи підтримку виробництв навіть в тих зонах, де обмеження ще не були повністю введені. Це в свою чергу ускладнює припинення теперішньої пандемії й одночасно збільшує їі масштаби [15].

Заходи, котрі застосовуються урядами для уповільнення розповсюдження вірусу, змусили людей у всьому світі змінити свою фінансову поведінку. Цікаво, що багато людей через введення жорстких карантинних обмежень та закриття бізнесу змогли заощадити більше грошей. Наприклад, більше $30 \%$ респондентів у Гонконгу, Франції, Індонезії, Китаї та Індії заявили, що заощадили більше грошей протягом 2020 року. 3 іншого боку, деякі люди були змушені використати свої попередні заощадження або навіть позичити більше грошей для того щоб забезпечити нормальну життєдіяльність в період кризи. Зокрема, більше $20 \%$ респондентів у Мексиці, Об'єднаних Арабських Еміратах та Індії були змушені взяти в борг, щоб подолати важку ситуацію, спричинену спалахом COVID-19 [12]. Ао прикладу, у 2020 році економіка Італії найбільше постраждала від впливу пандемія COVID-19. Відповідно, невизначена економічна ситуація, призвела до більш обережної поведінки серед споживачів, що посприяло високому рівню економії. Рівень заощаджень домогосподарств у 2020 році зріс до 15,2\%. Аналізуючи рівень заощаджень домогосподарств в Італії, бачимо, що сприятливі економічні умови сприяють збільшенню витрат, що призводить, як наслідок, до падіння рівня заощаджень, а кризова ситуація - навпаки спонукає домогосподарства до життя в умовах економії.

Основними наслідками пандемії COVID-19 для світової економіки вже є: падіння індексів бірж; суттєве зниження цін на нафту та уповільнення розвитку ринку металів; скорочення промислового виробництва; суттєве зниження доходів авіакомпаній та морського транспорту, торгово-розважальних центрів, туристичної індустрії; зменшення доходів населення; зростання 
прибутків фармацевтичної промисловості та світової індустрії ігрових, освітніх та інших онлайн-додатків; зростання попиту інвесторів на менш ризикові активи. За такої ситуації вже відбувається зниження економічного зростання світової економіки (з 2,5\% до $0,6 \%$ ). У 2020 році на загальносвітовому рівні економічна ситуація буде близька до рецесії, збитки світової економіки можуть досягнути \$2,7 трлн. Аля економіки України криза, зумовлена поширенням COVID-19, є особливо небезпечною і може суттєво похитнути фінансово-економічний стан країни: відбудеться падіння офіційної зайнятості та реального ВВП, значних втрат зазнає корпоративний сектор, знизяться шанси успішного розміщення єврооблігацій, скоротиться приплив іноземних інвестицій, відбудеться здешевлення національної валюти. За оптимістичного сценарію падіння економіки $\mathrm{У}_{\mathrm{K}-}$ раїни через поширення COVID-19 у 2020 році складе 4$5 \%$ ВВП, за найгіршого сценарію - 9-10\% [4].

Усе вищесказане свідчить про необхідність вжиття виважених рішень урядами країн світу та органами місцевої влади, які у тісній співпраці з провідними експертами, корпоративним сектором і населенням повинні провадити ефективну соціально-економічну політику як в умовах карантину, так і протягом наступних місяців після його завершення. Перспективами подальших досліджень $є$ проведення аналізу економічних наслідків карантину, втрат світової економіки після подолання коронавірусної хвороби та реальних заходів, яких було вжито для стабілізації фінансово-економічної ситуації на мікро- та макрорівнях.

Макроекономічні наслідки впливу пандемії на світову економіку:

1) інфляція, яка знецінює людські заощадження;

2) падіння цін на нафту;

3) спад виробництва, що призвів до скорочення світового ВВПна 4,36\% порівняно 3 попереднім роком;

4) зростання світового рівня безробіття;

5 уповільнення темпів росту світової торгівлі;

6) порушенням функціонування світової транспортної системи, спричинили перебої у роботі міжнародних ланцюгів постачання, що призвело до негативних соціальних та економічних наслідків у відповідних країнах;

7) збільшення державних видатків на фінансування охорони здоров'я та виготовлення медичних виробів у цілому світі, що матиме значний вплив на інші частини державного бюджету. Це призведе до того, що країни Західної Европи, ймовірно, будуть змушені скоротити військові видатки;

8) рецесія ЄС та США дає шанс Китаю швидше зменшити різницю в своєму економічному потенціалі. Китай спробує перетворити застій у світовій торгівлі на користь для себе. Наприклад, китайські інвестори можуть бути зацікавлені у викупі високотехнологічних іноземних компаній, які зараз особливо сильно ослаблені кризою.

Пандемія COVID-19 суттєво вплинула на поведінку споживачів у всьому світі (мікроекономічні наслідки), зокрема:

1) пандемія загострила необхідність споживачів розмірковувати про соціальні наслідки індивідуального способу життя;

2) під час карантинних обмежень важкий доступ до товарів та послуг змусив споживачів переоцінити схеми та потреби своїх закупівель, оскільки виникла необхідність приділяти основну увагу товарам першої необхідності. Я̆к наслідок, зріс попит на товари першої необхідності, проте різко знизився попит на товари вищої споживчої цінності;

3) пандемія змусила людей у всьому світі змінити свою фінансову поведінку відповідно багато людей через введення жорстких карантинних обмежень та закриття бізнесу змогли заощадити більше грошей;

4) пандемія спричинила невідповідність між споживацькими тенденціями та біофізичними потребами людей, адже під час введення жорстких карантинних об- межень поведінка багатьох споживачі стала тривожною, як результат, негативні очікування змусили споживачів панічно скуповувати велику кількість товарів першої необхідності (їжа, санітарно-гігієнічні товари).

\section{ВИСНОВКИ З ПРОВЕДЕНОГО ДОСЛІДЖЕННЯ І ПЕРСПЕКТИВИ ПОДАЛЬШИХ РОЗВІДОК У ДАНОМУ НАПРЯМІ}

Проведене дослідження свідчить про превалювання негативних наслідків впливу на економіку країн світу у зв'язку з поширенням пандемії. Зміна поведінки споживачів у зв'язку з карантинними обмеженнями визначила зменшення обсягів виробництва товарів та послуг у різних секторах економіки: транспортному, туристичному, ресторанному, промисловому та продовольчому. Попри негативні наслідки через зміну соціальних шаблонів поведінки індивідуумів, пандемію можна розглядати як "чорний лебідь", який очистив економіку від неплатоспроможних підприємств. Крім цього, в економіці активно почали розвиватися нові сервіси, зокрема сервіси доставки, побудовані на цифрових бізнес-моделях та сучасних мобільних додатках. Початкові оцінки впливу пандемії на провідні економіки світу значно переоцінені, адже фактичні дані 2020 року свідчать про скорочення обсягів виробництва в певних країнах та незначне падіння ВВП в інших через різну структуру економіки та поведінку економічних агентів. Секторами, в яких відбулося найбільше скорочення обсягів доходів, торгівельних операцій та послуг, стали такі: туризм, цивільна авіація, промислове виробництво (карантинні обмеження призвели до повної зупинки деяких виробництв), сфера роздрібної торгівлі, індустрія розваг та спорту тощо. У країнах, в яких частка цих секторів у ВВП була найбільшою, більшою мірою постраждали від стрімкого поширення пандемії.

Подальші перспективи досліджень доцільно спрямувати на виявлення шаблонів поведінки індивідуумів, зокрема з метою працевлаштування в умовах поширення пандемії, в різних секторах економіки. Потребує також нагального дослідження зв'язок зміни поведінки споживачів з діловою активністю в різних секторах економіки, котрій в майбутньому будуть зазнавати впливу різноманітних вірусних пандемій.

\ітература:

1. Гололобова О., Чмельова О. Вплив коронавірусу COVID-19 на світову економіку. Вісник Національного технічного університету" Харківський політехнічний інститут"(економічні науки). 2020. № 3. С. 67-72.

2. Грицюк H.О., Сак Т.В. Вплив пандемії COVID-19 на світову економіку. Економічний простір. 2021. № 165. C. $33-38$.

3. Гурріа К. и др. Вплив COVID-19 на світову економіку. Інноваційний розвиток сучасної економіки: нові підходи та актуальні дослідження. С. 15.

4. Аолбнєва А.В. Вплив COVID-19 на економіку країн світу. Проблемы экономики. 2020. № 1 (43). С. 20-26.

5. Радченко М.О., Рудь В.О. Вплив COVID-19 на розвиток світової економіки та організацію роботи сферу туризму. Харківський торговельно-економічний коледж КНТЕУ. 2021. С. 90-94.

6. Талеб Н. Антикрихкість: Про (не) вразливе у реальному житті. Наш формат, 2018.

7. Терещук C.B., Назаров M.I. Вплив COVID-19 на світове господарство. Актуальні проблеми економіки, обліку, фінансів, маркетингу та права. 2021. С. 19.

8. Якимишин I. Вплив COVID-19 на економіку країн світу. Грааль науки. 2021. № 4. С. $50-52$.

9. Eurostat (2020). European Economic Forecast Autumn 2020. P. 99. URL: https://ec.europa.eu/info/sites/ info/files/economy-finance/ip136_en_2.pdf

10. Nasdaq (2021). Crude oil price. $\bar{H}$ istorical data. URL: https://www.nasdaq.com/ market-activity/commodities/ $\mathrm{cl} \% 3 \mathrm{Anmx} /$ historical 
11. Slider P. (2020). Wplyw COVID-19 na swiatowg gospodarke. URL: https:// naszbiznes24.pl/wplyw-covid19-na-swiatowa-gospodarke

12. Statista (2021). Change in financial behaviors due to coronavirus (COVID-19) in selected countries worldwide. URL: https://www.statista.com/statistics/1220152/changing-financial-behaviors-due-to-covid-19-worldwide/

13. Statista (2021). Gross domestic product growth rate forecasts in selected European countries in 2021. URL: https://www.statista.com/statistics/1102546/ coronaviruseuropean-gdp-growth/

14. Statista (2021). Growth of the global gross domestic product (GDP) from 2015 to 2026 (compared to the previous year). URL: https://www.statista.com/statistics/273951/ growth-of-the-global-gross-domestic-product-gdp/

15. Statista (2021). Impact of the coronavirus pandemic on the global economy - Statistics \& Facts. URL: https:// www.statista.com/topics/6139/covid-19-impact-on-theglobal-economy

16. Statista (2021). The 15 countries with the highest gross domestic product (GDP) in 2030(in billion U.S. dollars). URL: https://www.statista.com/statistics/271724/ forecast-for-the-countries-with-the-highest-grossdomestic-product-gdp-in-2030/

17. Statista (2021). United States: Unemployment rate from 1999 to 2020 . URL: https://www.statista.com/statistics/ 263710/ unemployment-rate-in-the-united-states/

18. TED official site (2021). URL: https://www.ted.com/ speakers/bill gates

19. UNCT⿱乛龰D (2020a). World Investment Report 2020: International Production Beyond the Pandemic. United Nations publication. URL: https://investmentpolicy.unctad.org/news/hub/1647/20200616-world-investment-report2020---international-production-beyond-the-pandemic

20. UNCTAD (2020b). Impact of the COVID-19 pandemic on trade and development transitioning to a new normal. URL: https://unctad.org/system/files/officialdocument/osg2020d1 en.pdf

21. UNWTO $(202 \overline{0})$. International tourism and Covid19. URL. https://www.unwto.org/tourism-and-covid-19unprecedented-economic-impacts

22. World Bank (2021). World Development Indicators. URL: https://databank.worldbank.org/reports.aspx?sour$\mathrm{ce}=$ world-development-indicators\#

23. World Health Organization (2021). WHO coronavirus COVID-19 dashboard. URL: https:// covid19.who.int/

\section{References:}

1. Gololobova, O. and Chmelyova, O. (2020), "The impact of coronavirus COVID-19 on the world economy", Visnyk Natsional'noho tekhnichnoho universytetu" Kharkivs'kyy politekhnichnyy instytut"(ekonomichni nauky), vol. 3, pp. 67-72.

2. Gritsyuk, N. O. and Sak, T. V. (2021), "The impact of the COVID-19 pandemic on the world economy", Ekonomichnyy prostir, vol. 165 , pp. $33-38$.

3. Matsiura, S.I. and Chernenko, M.O. (2021), "The impact of COVID-19 on the world economy", Innovatsiynyy rozvytok suchasnoyi ekonomiky: novi pidkhody ta aktual'ni doslidzhennya, available at: https://dspace.znu.edu.ua/ $\mathrm{xmlui} / \mathrm{bits}$ tream/handle/12345/5203/BNPK200421. pdf? sequence $=1 \&$ isAllowed $=y$ (Accessed 5 June 2021).

4. Dolbneva, D. V. (2020), "Influence of COVID-19 on the economy of the world", Problemy ekonomyky, vol. 1 (43), pp. $20-26$.

5. Radchenko, L. O. and Rud, V, O. (2021), "Influence of COVID-19 on the development of the world economy and the organization of work in the field of tourism", Kharkivs'kyy torhovel'no-ekonomichnyy koledzh KNTEU, pp. 90-94, available at: https://ojs.htek.com.ua/index.php/ htek/article/view/127 (Accessed 5 June 2021).

6. Taleb, N. (2018), Antykrykhkist': Pro (ne) vrazlyve u real'nomu zhytti [Anti-fragility: About (not) vulnerable in real life], Our format, Kyiv, Ukraine.
7. Tereshchuk, S. V. and Nazarov, M. I. (2021), "The impact of COVID-19 on the world economy", Aktual'ni problemy ekonomiky, obliku, finansiv, marketynhu ta prava, available at: http://www.economics.in.ua/2021/05/ 1.html (Accessed 5 June 2021).

8. Yakimyshyn, I. (2021), "The impact of COVID-19 on the economy of the world", Hraal' nauky, vol. 4, pp. 50-52.

9. The official site of Eurostat (2020), "European Economic Forecast - Autumn 2020", available at: https:// ec.europa.eu/info/sites/info/files/economy-finance/ ip 136 en 2.pdf (Accessed 5 June 2021).

$1 \overline{0}$. The official site of Nasdaq (2021), "Crude oil price. Historical data", available at: https://www.nasdaq.com/ market-activity/commodities/cl\%3Anmx/historical (Accessed 5 June 2021).

11. Slider, P. (2020), "The impact of COVID-19 on the global economy", available at: https://naszbiznes24.pl/wplywcovid-19-na-swiatowa-gospodarke (Accessed 5 June 2021).

12. The official site of Statista (2021), "Change in financial behaviors due to coronavirus (COVID-19) in selected countries worldwide", available at: https:/ www.statista.com/statistics/1220152/changing-financialbehaviors-due-to-covid-19-worldwide/ (Accessed 5 June 2021).

13. The official site of Statista (2021), "Gross domestic product growth rate forecasts in selected European countries in 2021", available at: https://www.statista.com/ statistics/1102546/coronavirus-european-gdp-growth/ (Accessed 5 June 2021).

14. The official site of Statista (2021), "Growth of the global gross domestic product (GDP) from 2015 to 2026 (compared to the previous year)", available at: https:// www.statista.com/statistics/273951/grow th-of-the-globalgross-domestic-product-gdp/ (Accessed 5 June 2021).

15. The official site of Statista (2021), "Impact of the coronavirus pandemic on the global economy - Statistics \& Facts", available at: https://www.statista.com/topics/ 6139/covid-19-impact-on-the-global-economy (Accessed 5 June 2021).

16. The official site of Statista (2021), "The 15 countries with the highest gross domestic product (GDP) in 2030(in billion U.S. dollars)", available at: https://www.statista.com/statistics/271724/forecast-for-the-countrieswith-the-highest-gross-domestic-product-gdp-in-2030/ (Accessed 5 June 2021).

17. The official site of Statista (2021), "United States: Unemployment rate from 1999 to 2020", available at: https:/ /www.statista.com/statistics/263710/unemployment-ratein-the-united-states/ (Accessed 5 June 2021).

18. The official site of TED (2021), available at: https:// www.ted.com/speakers/bill_gates (Accessed 5 June 2021).

19. The official site of UNCTAD (2020), "World Investment Report 2020: International Production Beyond the Pandemic. United Nations publication", available at: https://investmentpolicy.unctad.org/news/hub/1647/ 20200616-world-investment-report-2020---internationalproduction-beyond-the-pandemic (Accessed 5 June 2021).

20. The official site of UNCTAD (2020), "Impact of the COVID-19 pandemic on trade and development transitioning to a new normal", available at: https://unctad.org/ system/files/official-document/osg2020d1_en.pdf (Accessed 5 June 2021).

21. The official site of UNWTO (2020), "International tourism and Covid-19", available at: https://www.unwto.org/tourism-and-covid-19-unprecedented-economicimpacts (Accessed 5 June 2021).

22. The official site of World Bank (2021), "World Development Indicators", available at: https://databank.worldbank.org/reports.aspx?source=world-developmentindicators\# (Accessed 5 June 2021).

23. The official site of World Health Organization (2021), "WHO coronavirus COVID-19 dashboard", available at: https://covid19.who.int/ (Accessed 5 June 2021).

Стаття надійила до редакиї 08.07.2021 p. 